Jurnal Keperawatan Silampari

Volume 3, Nomor 2, Juni 2020

e-ISSN: 2581-1975

p-ISSN: 2597-7482

DOI: https://doi.org/10.31539/jks.v3i2.1053

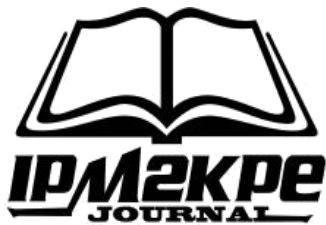

\title{
PENINGKATAN SELF EFFICACY PADA KELUARGA DENGAN PENYAKIT TB PARU MELALUI TERAPI PSIKOEDUKASI
}

\author{
Mochamad Heri ${ }^{1}$, Putu Karisma Dewi ${ }^{2}$, Gede Budi Widiarta ${ }^{3}$, Made Martini $^{4}$ \\ Sekolah Tinggi Ilmu Kesehatan Buleleng ${ }^{1,2,3,4}$ \\ mochamad_heri@rocketmail.com ${ }^{1}$
}

\begin{abstract}
ABSTRAK
Penelitian ini bertujuan untuk mengetahui pengaruh terapi psikoedukasi terhadap peningkatan self efficacy pada keluarga dengan penyakit TB Paru di Rumah Sakit Umum Kertha Usada. Desain penelitian yang digunakan adalah quasi experimental dengan rancangan pre-post test with control group design. Hasil penelitian menunjukkan rata-rata (mean) pre-test pada kelompok perlakuan adalah 20,56 dan pada kelompok kontrol adalah 21,04. Hasil rata-rata (mean) post-test pada kelompok perlakuan adalah 31,51 dan pada kelompok kontrol didapatkan hasil 30,57. Hasil uji parametrik menggunakan uji paired sample T-test didapatkan p-value $=(0,000)<\alpha$ $(0,05)$. Simpulan, ada pengaruh terapi psikoedukasi terhadap peningkatan self efficacy pada keluarga dengan penyakit TB paru di Rumah Sakit Umum Kertha Usada.
\end{abstract}

Kata Kunci: Self Efficacy, Terapi Psikoedukasi Keluarga, Tuberkulosis Paru

\section{ABSTRACT}

This study aims to determine the effect of psychoeducation therapy on increasing selfefficacy in families with pulmonary $T B$ disease at Kertha Usada General Hospital. Method: The research design used quasi-experimental with pre-post test with control group design. Results: The results showed the mean (mean) pre-test in the treatment group was 20.56 and in the control group was 21.04. The mean post-test mean in the treatment group was 31.51 and in the control group, the results were 30.57. Parametric test results using the Paired Sample T-test obtained p-value $=(0,000)<\alpha(0.05)$. Conclusion, there is an effect of psychoeducation therapy on increasing self-efficacy in families with Pulmonary of TB in Kertha Usada General Hospital.

Keywords: Self-Efficacy, Family Psychoeducation Therapy, Tuberculosis

\section{PENDAHULUAN}

Penelitian yang dilakukan oleh Rosdiana (2018) melakukan penelitian untuk mengetahui faktor yang berhubugan dengan kejadian tuberkulosis paru. Penelitian ini merupakan jenis penelitian deskriptif dengan pendekatan cross sectional study. Populasi pada penelitian ini adalah pasien 190 orang dengan sampel sebanyak 58 orang. Pengolahan data dilakukan dengan menggunakan program spss dan analisis data dengan menggunakan tabel univariat dan bivariat. Hasil penelitian diperoleh bahwa ada hubungan antara kebiasaan merokok dengan kejadian tuberkulosis paru karena nilai $\mathrm{p}$ $(0.008)<\alpha=0,005$, ada hubungan antara pendapatan dengan kejadian tuberkulosis paru 
karena $\mathrm{p}(0.007)<\alpha=0,05$ dan tidak ada hubungan antara komsumsi alkohol dengan kejadian tuberkulosis paru karena nilai $\mathrm{p}(0.194)>\alpha=0.05$.

Penelitian tentang tuberkulosis paru yang dilakukan oleh Sumarsih, Wahyuningsih (2019) untuk mengetahui perubahan tingkat ansietas dan stres pasien Tuberkulosis paru sebelum dan setelah diberikan relaksasi spiritual di RS PKU Muhammadiyah Sruweng. Penelitian ini menggunakan metode quasi experiment dengan rancangan one grup pre test - post test design. Sampel dalam penelitian ini sebanyak 65 responden dan pengambilan sampel dilakukan dengan metode total sampling. Tingkat ansietas dan stres diukur menggunakan kuesioner DASS-42 dengan 14 item pernyataan. Data berdistibusi normal dengan uji normalitas data menggunakan kolmogorov-smirnov, sedangkan analisa data menggunakan uji paired t-test. Hasil penelitian ini merekomendasikan bahwa metode relaksasi spiritual direkomendasikan dalam intervensi keperawatan suportif sebagai upaya menurunkan tingkat ansietas dan stres pasien tuberkulosis paru.

Selain permasalahan ansietas dan stress pada pasien tuberkulosis paru, masalah efikasi diri menjadi hal penting yang perlu mendapatkan perhatian lebih jauh. Self efficacy memiliki pengaruh yang signifikan pada kepatuhan minum obat. Pada penelitian yang dilakukan oleh Kawulusan, Katuuk, \& Bataha (2019) menyatakan bahwa hasil uji statistik menggunakan uji fisher's exact menunjukkan nilai $\mathrm{p}=0,000$ dengan tingkat kepercayaan 95\% derajat kemaknaan $\alpha=0,05$ yang berarti $p=0,000<p$ $=0,05$ untuk self-efficacy dan kepatuhan minum obat. Hasil penelitiannya yang dilakukan pada pasien dengan hipertensi menyimpulkan bahwa terdapat hubungan signifikan antara self-efficacy dengan kepatuhan minum obat di Puskesmas Ranotana Weru Kota Manado.

Profil kesehatan RI tahun 2017 menunjukkan presentase kasus tuberkulosis terbanyak ditemukan pada kelompok umur 25-34 tahun yaitu sebesar7,2\% diikuti kelompok umur 45-54 tahun sebesar 17,1\% dan pada kelompok umur 35-44 tahun sebesar 16,4\%. Di Indonesia jumlah kasus baru TB sebanyak 420.994 kasus pada tahun 2017. Berdasarkan jenis kelamin, jumlah kasus baru TBC tahun 2017 pada laki-laki 1,4 kali lebih besar dibandingkan pada perempuan. Bahkan berdasarkan Survei Prevalensi Tuberkulosis prevalensi pada laki-laki 3 kali lebih tinggi dibandingkan pada perempuan. Hal ini terjadi kemungkinan karena laki-laki lebih terpapar pada faktor risiko TBC misalnya merokok dan kurangnya ketidakpatuhan minum obat. Hasil survei menunjukkan bahwa dari seluruh partisipan laki-laki yang merokok sebanyak $68,5 \%$ dan 3,7\% partisipan perempuan yang merokok (Kemenkes RI, 2018).

Keluarga merupakan unit terkecil atau unit dasar dari suatu masyarakat yang sangat berpengaruh terhadap derajat kesehatan masyarakat itu sendiri. Menurut tugas keluarga dibidang kesehatan antara lain: mengenal masalah kesehatan yang dihadapi anggota keluarga, membuat keputusan secara tepat dalam mengatasi masalah kesehatan anggota keluarga, memberi perawatan pada anggota keluarga yang mempunyai masalah kesehatan, memodifikasi lingkungan yang kondusif dan dapat memanfaatkan fasilitas pelayanan kesehatan untuk pemeliharaan dan perawatan anggota keluarga yang sakit. Keluarga yang melakukan perawatan pada anggota keluarga yang sakit membutuhkan dukungan anggota keluarga lainnya agar memiliki keyakinan diri (self efficacy) yang baik.

Efikasi diri merupakan suatu proses kognitif terkait kenyamanan individu dalam melakukan suatu hal sehingga mempengaruhi motivasi, proses berpikir, kondisi emosional serta lingkungan sosial yang menunjukkan suatu kebiasaan yang spesifik. 
Efikasi diri yang tinggi dapat meningkatkan pengobatan TB-MDR sedangkan efikasi diri yang rendah akan berakibat pada kegagalan pengobatan (Hasanah, Wahyudi, 2018).

Dalam penelitian yang dilakukan oleh Ramadhayanti, Cahyu, \& Widagdo (2018) menyatakan bahwa self efficacy merupakan bentuk dukungan untuk meningkatkan fungsi keluarga yang dapat diberikan agar kualitas hidup klien tetap maksimal. Salah satu fungsi dari self efficacy adalah memberikan keyakinan bahwa seseorang akan berhasil dalam melakukan perawatan dirinya asalkan optimal dalam melakukan kegiatan yang menunjang pada status kesehatan.

Muhtar (2018) menyatakan self efficacy mampu untuk merubah perilaku, memotivasi keluarga untuk terus belajar memberikan perawatan yang terbaik, menjaga dari kekambuhan. Keluarga perlu mendapatkan terapi untuk memperkuat strategi koping dalam menangani perubahan mental klien. Terapi keluarga merupakan intervensi spesifik dengan tujuan membina komunikasi secara terbuka dan interaksi keluarga secara sehat.

Penelitian yang dilakukan Ahmad, Pulungan, \& Hardiyati (2019) tentang psikoedukasi pada pasien dengan gangguan jiwa. Penelitian ini merupakan penelitian pra eksperimen dengan desain pre - post test without control group design. Populasi dalam penelitian ini adalah caregiver yang mempunyai anggota keluarga gangguan jiwa di wilayah kerja Puskesmas Tampapadang. Sampel diperoleh dengan purposive sampling berjumlah 23 keluarga. Data dianalisa menggunakan uji paired t-test untuk mengetahui kemampuan kognitif keluarga sebelum dan sesudah psikoedukasi. Hasil penelitian menunjukkan ada peningkatan kemampuan kognitif keluarga setelah diberikan psikoedukasi dengan nilai $\mathrm{p}=0,000$. Kesimpulannya psikoedukasi pada keluarga meningkatkan peran keluarga dalam merawat klien gangguan jiwa.

Pemberdayaan keluarga dalam peningkatan self efficacy dan self care acitivity keluarga dalam perawatan penderita TB paru pada kelompok perlakuan sebelum dan sesudah diberikan perlakuan mengalami peningkatan (Muhtar, 2018). Pada kelompok perlakuan sebelum diberikannya intervensi mendapatkan hasil sebanyak 50\% keluarga memiliki self efficacy dan self care activity yang kurang. Setelah diberikan intervensi mendapatkan hasil 56,2\% keluarga yang memiliki self efficacy dan self care activity yang baik. Perlakuan yang diberikan yaitu berupa pengetahuan mengenai konsep penyakit TB paru serta aktifitas perawatan mandiri penderita TB paru yang diberikan selama perlakuan dengan metode penyuluhan kesehatan, bimbingan konseling, serta demonstrasi cara perawatan mandiri penderita TB paru di rumah. Pemberdayaan keluarga yang diberikan perlakuan berupa bimbingan konseling bisa diberikan dalam terapi psikoedukasi.

Berdasarkan studi pendahuluan yang dilakukan pada tanggal 14 Januari 2019 di poliklinik paru Rumah Sakit Umum Kertha Usada tercatat dari bulan Oktober sampai dengan bulan Desember 2018 sebanyak 300 orang masuk dalam perawatan TB paru. Sebanyak 12 orang dinyatakan menderita suspect TB, 288 orang menderita TB paru. Dengan wawancara didapatkan hasil bahwa dari 10 keluarga penderita TB paru mengatakan masih kurang mendukung klien karena tidak mengetahui informasi tentang bagaimana cara untuk memberikan asuhan keperawatan pada anggota keluarga yang menderita TBC. Sedangkan dari 10 responden penderita TBC mengatakan sedih dengan keadaan dirinya, karena sering batuk dan merasa malu ketika batuk. Penderita juga menyatakan bahwa ketika ingin batuk, penderita memisahkan diri dulu dari orang disekitarnya karena penderita takut diketahui orang lain bahwa dirinya menderita TB 
paru. Penderita juga menyatakan bahwa jika hendak batuk, penderita menutup mulut dan menahan batuknya agar tidak terdengar oleh orang lain (data primer peneliti, 2019). Melihat fenomena tersebut diatas akhirnya penulis merasa penting untuk melakukan penelitian tentang masalah psikososial keluarga klien penderita TB paru dengan melihat "pengaruh terapi psikoedukasi terhadap peningkatan self efficacy pada keluarga dengan penyakit TB paru di Rumah Sakit Umum Kertha Usada".

Penelitian tentang TB paru telah banyak dilakukan. Namun penyakit ini masih menjadi salah satu penyakit menular yang menjadi program pemerintah. Penelitian ini lebih memfokuskan pada keyakinan diri keluarga dalam merawat anggota kelurga yang menderita TB paru. Pendekatan yang digunakan adalah pendekatan keluarga. Penelitian-penelitian tentang pendekatan keluarga dengan fokus keyakinan keluarga masih sangat terbatas. Selain itu, keluarga yang merupakan bagian penting dari penderita TB paru sebagai sistem pendukung yang adekuat bila saat menghadapi masalah tidak mendapatkan solusi yang terbaik dan akhirnya akan berdampak kepada program penanggulangan tuberkulosis itu sendiri.

\section{METODE PENELITIAN}

Penelitian ini merupakan penelitian eksperimen dimana subyek penelitiannya adalah keluarga yang melakukan perawatan pada penderita TB paru di Rumah Sakit Umum Kertha Usada, karena dalam penelitian memberikan perlakuan atau intervensi pada objek yang akan diteliti. Desain yang digunakan dalam penelitian ini yaitu quasi experimental dengan rancangan pre-post test with control group design. Teknik sampling yang digunakan adalah purposive sampling dengan jumlah sampel sebanyak 82 responden pada kelompok kontrol dan 82 responden pada kelompok perlakuan. Penelitian ini menggunakan alat ukur kuesioner self efficacy dan dilakukan selama 3 minggu di Rumah Sakit Umum Kertha Usada.

Pemilihan sampel dilakukan sesuai sesuai kriteria inklusi dan kriteria ekslusi, kriteria inklusi yaitu keluarga yang mempunyai anggota keluarga dengan TB Paru dirawat di RSU Kerta Usada dan bersedia menjadi responden, kemudian dari sampel tersebut dibagi menjadi dua kelompok yaitu kelompok yang diberikan tindakan (kelompok perlakuan) dan kelompok yang tidak diberikan tindakan psikoedukasi (kelompok kontrol).

Kelompok perlakukan diberikan tindakan yaitu pelaksanaan terapi Psikoedukasi yang dilaksanakan selama 3 (tiga) minggu terbagi menjadi 4 sesi, sesi pertama dan kedua dilakukan pada minggu pertama, sesi ketiga dilakukan pada minggu kedua dan sesi keempat dilakukan pada minggu ketiga, kemudian para responden diberikan Kuisioner terkait self efficacy dinilai menjadi 3 sub penilaian yaitu berdasarkan level (tingkat), generality (keadaan umum), serta strength (kekuatan), dalam kuisioner tersebut dibagi menjadi 3 (tiga penilaian) antara lain: kategori self efficacy tinggi dengan skor 31-40, kategori self efficacy sedang dengan skor yaitu 21- 30 dan kategori self efficacy rendah dengan skor 10-20. Dari data tersebut kemudian peneliti melakukan penelitian. Data diolah menggunakan program komputer. Kaji etik dalam penelitian ini dilakukan oleh Komite Etik Penelitian Kesehatan (KEPK) Sekolah Tinggi Ilmu Kesehatan Buleleng. 
HASIL PENELITIAN

Tabel. 1

Nilai Mean dan Standar Deviasi Berdasarkan Usia

\begin{tabular}{lccccc}
\hline Kelompok & N & Mean & SD & Min-Maks & $95 \%$ CI \\
\hline Kontrol & 82 & 41,52 & 8,598 & $23-67$ & $39,64-43,41$ \\
Perlakuan & 82 & 36,83 & 9,489 & $25-66$ & $34,74-38,91$ \\
\hline
\end{tabular}

Sumber: Data Primer (2019)

Berdasarkan tabel diatas menunjukkan bahwa rata-rata usia responden pada kelompok kontrol adalah 41,52 tahun dan pada kelompok perlakuan 36,83 tahun.

Tabel. 2

Distribusi Frekuensi Kelompok

Kontrol dan Perlakuan

\begin{tabular}{|c|c|c|c|c|}
\hline \multirow{2}{*}{$\begin{array}{r}\text { Variabel } \\
\text { Jenis Kelamin }\end{array}$} & \multicolumn{2}{|c|}{ Kontrol } & \multicolumn{2}{|c|}{ Perlakuan } \\
\hline & Frekuensi (f) & Persentase $(\%)$ & Frekuensi (f) & Persentase (\%) \\
\hline Laki & 50 & 61 & 43 & 52,4 \\
\hline Perempuan & 32 & 39 & 39 & 47,6 \\
\hline \multicolumn{5}{|l|}{ Pendidikan } \\
\hline Tidak Sekolah & 0 & 0 & 2 & 2,4 \\
\hline SD & 8 & 9,8 & 16 & 19,5 \\
\hline SMP & 24 & 29,3 & 33 & 40,2 \\
\hline SMA & 36 & 43,9 & 24 & 29,3 \\
\hline Diploma & 1 & 1,2 & 4 & 4,9 \\
\hline Sarjana & 13 & 15,9 & 3 & 3,7 \\
\hline \multicolumn{5}{|l|}{ Status Merokok } \\
\hline Merokok & 46 & 56,1 & 45 & 54,9 \\
\hline Tidak Merokok & 36 & 43,9 & 37 & 45,1 \\
\hline \multicolumn{5}{|l|}{ Pekerjaan } \\
\hline Tidak Bekerja & 1 & 1,2 & 2 & 2,4 \\
\hline Petani/Pedagang/B & 37 & 45,1 & 40 & 48,8 \\
\hline uruh & 8 & 9,8 & 1 & 1,2 \\
\hline PNS/TNI/POLRI & 36 & 43,9 & 39 & 47,6 \\
\hline Lain-lain & & & & \\
\hline \multicolumn{5}{|l|}{$\begin{array}{l}\text { Penghasilan } \\
\text { perbulan }\end{array}$} \\
\hline Rp. $\quad 500.000-$ & 49 & 59,8 & 57 & 69,5 \\
\hline 1.000 .000 & 22 & 26,8 & 21 & 25,6 \\
\hline $\operatorname{Rp} \quad 1.500 .000-$ & 11 & 13,4 & 4 & 4,9 \\
\hline \multirow{2}{*}{\multicolumn{5}{|c|}{$\begin{array}{l}2.000 .000 \\
\text { Rp 2.000.000 lebih }\end{array}$}} \\
\hline & & & & \\
\hline Total & 82 & 100 & 82 & 100 \\
\hline
\end{tabular}

Sumber: Data Primer (2019)

Berdasarkan jenis kelamin sebagian besar responden adalah laki-laki, pada kelompok kontrol sebanyak 50 orang (61\%) sedangkan pada kelompok perlakuan sebanyak 43 orang $(52,4 \%)$. Berdasarkan tingkat pendidikan, pada kelompok kontrol sebagian besar memiliki tingkat pendidikan. SMP sebanyak 24 orang (29,3\%), pada kelompok perlakuan sebagian besar memiliki tingkat pendidikan SMA sebanyak 24 orang $(29,3)$. Berdasarkan status merokok sebagian besar responden memiliki status 
sebagai perokok, pada kelompok kontrol sebanyak 46 orang $(56,1 \%)$ dan pada kelompok perlakuan $45(54,9 \%)$. Pada data pekerjaan sebagian besar responden memiliki perkerjaan sebagian buruh/pedagang/petani yaitu pada kelompok kontrol sebagian besar yaitu petani/pedagang/buruh sebanyak 37 (45,1\%) dan pada kelompok perlakuan yaitu sebanyak $40(48,8 \%)$, Sedangkan berdasarkan penghasilan perbulan sebagian besar responden baik kelompok perlakauan dan kelompok kontrol memiliki penghasilan perbulan yaitu Rp. 500.000-1.000.000, pada kelompok kontrol sebanyak 49 orang $(59, \%)$ dan pada kelompok perlakuan sebanyak 57 orang $(69,5 \%)$.

Tabel. 3

Distribusi Frekuensi Skor Self Efficacy pada Keluarga dengan Penyakit TB Paru Sebelum dan Sesudah Diberikan Intervensi pada Kelompok Kontrol dan Perlakuan

\begin{tabular}{cccccc}
\hline \multirow{2}{*}{ No } & \multirow{2}{*}{ Self Efficacy } & \multicolumn{2}{c}{ Pre Test } & \multicolumn{3}{c}{ Post Test } \\
& \multicolumn{8}{c}{ F } & $\%$ & F & $\%$ \\
\hline & Rendah & 34 & 41,5 & - & - \\
2 & Sedang & 48 & 58,5 & 48 & 58,5 \\
3 & Tinggi & - & - & 34 & 41,5 \\
\hline \multicolumn{7}{r}{} & Total & 82 & 100 & 82 & 100 \\
1 & Rendah & 42 & 51,2 & - & - \\
2 & Sedang & 40 & 48,8 & 26 & 31,7 \\
3 & Tinggi & - & - & 56 & 68,3 \\
\hline & Total & 82 & 100 & 82 & 100 \\
\hline
\end{tabular}

Sumber: Data Primer (2019)

Berdasarkan tabel diatas diketahui bahwa tingkat self efficacy pada kelompok kontrol sebelum intervensi, sebagian besar dalam kategori sedang, yaitu 48 responden $(58,5 \%)$. Setelah diberikan intervensi, semua responden mempunyai tingkat self efficacy dalam kategori sedang, yaitu 48 responden $(58,5 \%)$. Sedangkan tingkat self efficacy pada kelompok perlakuan pada saat pre test, sebagian besar berada dalam kategori rendah, yaitu 42 responden $(51,2 \%)$. Sedangkan pada saat post test, sebagian besar tingkat self efficacy responden berada dalam kategori tinggi, yaitu 56 responden $(68,3 \%)$.

Tabel. 4

Analisa Perbedaan Self Efficacy Sebelum dan Sesudah Diberikan Terapi Psikoedukasi pada Kelompok Perlakuan dan Kelompok Kontrol

\begin{tabular}{ccccc}
\hline & Mean & Std. Deviation & $\mathrm{T}$ & $p$-value \\
\hline $\begin{array}{c}\text { Pre-Posttest } \\
\text { Kontrol }\end{array}$ & $-9,537$ & 1,970 & $-43,834$ & 0,000 \\
$\begin{array}{c}\text { Pre-Posttest } \\
\text { Perlakuan }\end{array}$ & $-10,951$ & 2,154 & $-46,040$ & 0,000 \\
\hline
\end{tabular}

Sumber data primer (2019)

Berdasarkan tabel diatas Hasil uji t berpasangan pada kelompok perlakuan didapatkan nilai $\mathrm{t}-43,834$ dan p $0,000<0,05$, artinya terdapat perbedaan self efficacy sebelum dan setelah penerapan terapi psikoedukasi. Sedangkan hasil uji t test pada kelompok kontrol didapatkan nilai $t$ hitung $-46,040$ dan $p 0,000<0,05(\alpha)$, artinya 
terdapat perbedaan self efficacy pada saat pre test dan post test. Nilai negatif pada $\mathrm{t}$ menunjukkan bahwa nilai pre test lebih rendah dari pada nilai post test.

Tabel. 5

Analisa Data Nilai Post Perlakuan dan Kontrol

\begin{tabular}{ccll}
\hline Data & Mean & P-value & CI 95\% \\
\hline Post test Kontrol & 30,57 & 0,000 & \\
Post-test & 31,51 & 0,000 & $-0,94(1,381-(-497)$ \\
Perlakuan & & \\
\hline
\end{tabular}

Sumber data primer (2019)

Berdasarkan tabel diatas didapatkan hasil analisa statistik pada kedua kelompok didapatkan hasil rata-rata self efficacy sebesar 0,94. Selanjutnya pada nilai p didapatkan hasil 0,000 atau nilai $\mathrm{p}<0,05$ dan $95 \%$ CI $(-1,381-(-497)$ yang bermakna. Dapat disimpulkan bahwa ada pengaruh yang signifikan antara kelompok perlakuan dengan kelompok kontrol dalam pemberian terapi psikoedukasi terhadap peningkatan self efficacy pada keluarga dengan penyakit TB Paru di Rumah Sakit Umum Kertha Usada.

\section{PEMBAHASAN}

\section{Karakteristik Responden}

Dari karakteristik baik kelompok kontrol dan kelompok perlakuan diklasifikasikan berdasarkan jenis kelamin, pendidikan, umur, pekerjaan, dan pola kebiasaan merokok. Dari hasil penelitian ditemukan sebagian besar responden berjenis kelamin laki-laki baik kelompok perlakukan dan kelompok kontrol, dikatakan bahwa jenis kelamin tidak memiliki pengaruh signifikan dalam melaksanakan self efficacy, hal tersebut dikarekan masing-masing individu memiliki keyakinan tersendiri dalam melaksanakan self efficacy yang didasari oleh kesadaran dan kematangan seseorang (Muhtar, 2018).

Sejalan dengan penelitian yang dilakukan oleh Rosdiana (2018) menyatakan bahwa sebagaian besar perokok berjenis kelamin laki-laki. Penelitian dilakukan pada Rumah Sakit Labuang Baji. Berdasarkan penelitian tersebut menunjukkan bahwa dari 58 responden di Rumah Sakit Labuang Baji terdapat responden berjenis kelamin lakilaki sebanyak 56,9\% dan berjenis kelamin perempuan sebanyak 43,1\%. Kelompok umur tertinggi 46 - 55 tahun sebanyak $24,1 \%$ dan kelompok umur terendah $76-86$ sebanyak $1,7 \%$. Tingkat pendidikan tertinggi SD sebanyak $32,8 \%$ dan terendah sebanyak tidak sekolah dan S1 masing- masing sebanyak 3,4\%. Responden yang menderita tuberkulosis paru sebanyak $50 \%$ dan tidak menderita sebanyak $50 \%$. Dalam hasil penelitiannya Rosdiana juga menyatakan bahwa ada banyak faktor yang menyebabkan terjadinya kekambuhan dari penyakit TB paru antara lain pola kebiasaan merokok, disamping itu pendapatan atau perekonomian masyarakat dapat mempengaruhi pola perilaku seseorang dalam menjaga kesehatan.

Pada data pendidikan sebagian besar responden menempuh pendidikan dalam tingkat SMA pada kelompok kontrol dan sebagian besar pendidikan dalam tingkat SMP pada kelompok perlakuan. Dalam hal ini pendidikan akan mempengaruhi pengetahuan serta wawasan seseorang dan akan mempengaruhi kesadaran serta keyakinan seseorang akan pentingnya pelaksanaan self efficacy terutama pada saat melakukan perawatan pada keluarga yang mengalami TB paru, dikatakan pulan salah satu faktor yang mempengaruhi parenting self efficacy yaitu pendidikan formal, 
semakin tinggi pendidikan semakin tinggi pula parenting self efficacy (Sutarto et al, 2019).

Pada data pola kebiasaan merokok sebagian besar responden baik dalam kelompok kontrol dan perlakuan memiliki pola kebiasaan merokok, pola kebiasaan merokok sangat mempengaruhi kesehatan seseorang, apabila seorang penderita TB paru berada diantara keluarga yang memiliki kebiasaan merokok pastinya pasien tersebut akan terpapar asap rokok yang akan menghambat kesembuhan pasien dengan TB paru, dalam penelitian ini sebagian besar keluarga pasien memiliki kebiasaan merokok sehingga hal tersebut ada kaitannya dnegan kesadaran individu dan sangat erat berhubungan dengan self efficacy, tingginya angka kematian TB paru salah satu faktor yang mempengaruhi yaitu pola kebiasaan merokok atau terpapar asap rokok yang memperparah kondisi pasien (Kemenkes RI, 2018).

Adapun data pekerjaan sebagian besar responden memiliki perkerjaan sebagian buruh/pedagang/petani dengan rata-rata penghasilan perbulan yaitu sekitar Rp. 500.000-1.000.000. Dalam hal ini pekerjaan dan pendapatan keluarga sangat erat kaitannya dengan proses perawatan pasien dengan TB paru, dikhawatirkan apabila tingkat perekonomian keluarga rendah, keluarga tersebut tidak mampu lagi dalam memberikan pengobatan serta perawatan pasien dengan TB paru yang optimal karena keterbatasan biaya terutama dalam membeli obat serta memenuhi status gizi yang baik bagi penderita TB paru.

Hasil penelitian ini didukung oleh penelitian Ahmad, Pulungan, \& Hardiyati (2019) tentang "pengaruh terapi psikoedukasi keluarga terhadap self efficacy keluarga dan sosial okupasi klien schizophrenia" hasil dari penelitian ini menunjukkan bahwa perbedaan rerata antara post dan pretest self efficacy dari 22,88 menjadi 37,00 dan sosial okupasi dari 17,00 menjadi 31,94. Sehingga disimpulkan terdapat perbedaan yang bermakna setelah diberikan terapi, yaitu berupa terapi psikoedukasi keluarga terhadap self efficacy keluarga dan sosial okupasi klien schizophrenia pada kelompok kontrol. Nilai p $(0,000) \quad \alpha<0,005$ yang berarti ada pengaruh yang signifikan terapi psikoedukasi keluarga terhadap self efficacy keluarga dan sosial okupasi klien schizophrenia.

Sejalan dengan penelitian yang dilakukan oleh Ramadhayanti et al, (2018) menyatakan bahwa bahwa sebagian besar responden memiliki perilaku pencegahan drop out tuberkulosis pada keluarga penderita yang baik. Pencegahan drop out tuberculosis dikarenakan beberapa faktor yaitu sebagian besar responden memiliki persepsi keseriusan yang baik mengenai kejadian drop out tuberkulosis (58,3\%), persepsi keretanan yang baik mengenai kejadian drop out tuberkulosis $(62,5 \%)$, persepsi efikasi diri yang baik mengenai kejadian drop out tuberkulosis. Ketiga faktor tersebut memiliki pengaruh yang signifikan terhadap drop out tuberkulosis.

\section{Self Efficacy Sebelum dan Sesudah Diberikan Terapi Psikoedukasi}

Gambaran self efficacy keluarga dengan penyakit TB paru sebelum dan sesudah diberikan terapi psikoedukasi pada kelompok kontrol dan kelompok perlakuan di Rumah Sakit Umum Kertha Usada, hasil analisa yang diperoleh menunjukkan hasil bahwa pada kelompok kontrol sebagian besar responden memiliki self efficacy rendah sebanyak 34 responden $(41,5 \%)$ dan yang memiliki self efficacy sedang sebanyak 48 responden $(58,5 \%)$. Sedangkan pada kelompok perlakuan memiliki self efficacy rendah sebanyak 42 responden $(51,2 \%)$ dan yang memiliki self efficacy sedang sebanyak 40 responden $(48,8 \%)$. 
Self efficacy merupakan tingkat keyakinan diri terhadap kemampuan diri dalam melakukan dan meningkatkan kinerja dalam kehidupan mereka. Self efficacy dapat mempengaruhi bagaimana seseorang merasakan, berpikir, memotivasi dan berperilaku terhadap anggota keluarga yang lain, self efficacy merupakan salah satu bentuk dukungan untuk meningkatkan fungsi keluarga yang dapat diberikan agar meningkatkan kualitas hidup keluarga dalam hal ini kelurga yang menjalani perawatan oleh karena TB paru, peningkatan self efficacy keluarga sesudah diberikan intervensi pada kelompok perlakuan dan kelompok kontrol mengalami peningkatan yang signifikan (Sutarto et al, 2019). Pada kelompok kontrol dengan intervensi pemberian terapi psikoedukasi menggunakan metode audio visual (video) memiliki peningkatan yang lebih signifikan dibandingkan dengan kelompok perlakuan dengan pemberian terapi psikoedukasi menggunakan SOP. Hal tersebut dikarenakan sumber informasi utama yang dapat dipakai sebagai alat untuk menumbuhkan dan mengembangkan efikasi diri pada diri individu tersebut berbeda-beda antara lain : Sumber Pengalaman keberhasilan atau mastery experience, pengalaman orang lain atau vicarious experience, persuasi verbal atau verbal persuasion.

\section{Pengaruh Terapi Psikoedukasi terhadap Peningkatan Self Efficacy}

Analisis pengaruh terapi psikoedukasi terhadap peningkatan self efficacy pada keluarga dengan penyakit TB paru di Rumah Sakit Umum Kertha Usada, untuk mengetahui adanya pengaruh terapi psikoedukasi terhadap peningkatan self efficacy pada keluarga dengan penyakit tb paru di Rumah Sakit Umum Kertha Usada dilakukan dengan menggunakan uji paired simple t-test pada kedua kelompok. Pada kedua kelompok didapatkan nilai $p$ - value 0,000 dari analisis $<0,005$ yang berarti ada pengaruh terapi psikoedukasi terhadap peningkatan self efficacy pada keluarga dengan penyakit TB paru di Rumah Sakit Umum Kertha Usada. Hal tersebut sejalan dengan penelitian Ahmad et al, (2019) menyatakan bahwa pemberian terapi psikoedukasi dapat mempengaruhi persepsi serta motivasi keluarga dalam merawat pasien dengan penyakit kronik. Hasil penelitian yang dilakukan menunjukkan bahwa psikoedukasi dapat meningkatkan pengetahuan.

Hasil penelitian ini juga sejalan dengan penelitian lainnya tentang self efficacy pada pasien tuberkulosis. Pada penelitian yang dilakukan menunjukkan bahwa efikasi diri penderita tuberkulosis resisten obat merupakan keyakinan penderita akan kemampuannya untuk menjalani pengobatan tuberkulosis dalam jangka waktu yang ditentukan. Pengalaman baik langsung maupun tidak langsung dalam menjalani pengobatan tuberkulosis dapat menjadi pendorong tingginya efikasi diri penderita. Pengalaman tersebut mengajarkan penderita langkah tepat yang mampu memotivasi diri sehingga dapat menjadikan kebiasaan penderita untuk menjadi semakin mudah menjalani pengobatan tersebut. Peneliti meyakini bahwa motivasi dan pengalaman merupakan faktor penting yang menjadi pendorong tingginya Efikasi Diri penderita tuberkulosis resisten obat di RSUD Ibnu Sina Gresik (Hasanah et al, 2018).

\section{SIMPULAN}

Berdasarkan hasil analisis maka dapat disimpulkan bahwa setelah diberikan tindakan terapi psikoedukasi terutama pada keluarga pasien dengan penyakit TB paru maka ditemukan hasil bahwa ada pengaruh terapi psikoedukasi terhadap peningkatan self efficacy pada keluarga dengan penyakit TB paru di Rumah Sakit Umum Kertha Usada. 


\section{SARAN}

\section{Bagi Pelayanan}

Pelayanan perlu mempertimbangkan untuk menerapkan pemberian terapi Psikoedukasi untuk meningkatkan self efficacy pada pasien tuberkulosis yang memperoleh pengobatan.

\section{Bagi Keilmuan}

Hasil penelitian ini diharapkan dapat dijadikan sumber informasi bagi keperawatan. Selain itu, mampu memberikan pedoman atau bahan pertimbangan untuk mengembangkan penelitian di bidang keperawatan yang berkaitan dengan self efficacy dan terapi psikoedukasi serta memperhatikan alat ukur dan aspek-aspek lainnya. Selain itu pemberian terapi psikoedukasi ini tidak harus menggunakan pedoman SOP tetapi pemberian psikoedukasi dengan metode audio visual (video) juga bisa diterapkan dan lebih efektif dalam penerapannya.

\section{Bagi Penelitian Selanjutnya}

Hasil penelitian selanjutnya diharapkan dapat digunakan sebagai data dalam melakukan penelitian selanjutnya dalam upaya untuk pemberdayaan pasien tuberkulosis.

\section{DAFTAR PUSTAKA}

Ahmad, M., Pulungan, Z. S. A., \& Hardiyati, H. (2019). Psikoedukasi Meningkatan Peran Keluarga dalam Merawat Klien Gangguan Jiwa. Jurnal Keperawatan LPPM Stikes Kendal, 11(3), 191-198

Hasanah, M., \& Wahyudi, A. S. (2018). Hubungan Dukungan Keluarga dengan Efikasi Diri Penderita Tuberculosis Multidrug Resistant (Tb-MDR). Jurnal Kesehatan, 11(2), 72. https://doi.org/10.24252/kesehatan.v11i2.5415

Kawulusan, K. B., Katuuk, M. E., \& Bataha, Y. B. (2019). Hubungan Self-Efficacy dengan Kepatuhan Minum Obat Hipertensi di Puskesmas Ranotana Weru. Jurnal Keperawatan (E-Kp), 7(1), 1-9

Kemenkes RI. (2018). Hasil Utama Riset Kesehatan Dasar Kementrian Kesehatan Republik Indonesia

Muhtar, M. (2018). Pemberdayaan Keluarga dalam Peningkatan Self-Efficacy dan Self -Care Aktivitas Keluarga dan Penderita TB

Ramadhayanti, D. A., Cahyu, K., \& Widagdo, L. (2018). Faktor-Faktor yang Mempengaruhi Pencegahan Kejadian Drop Out Tuberkulosis pada Keluarga di Seluruh Wilayah Kerja Puskesmas Kota Semarang. Jurnal Kesehatan Masyarakat (E-Journal), 6(2), 163-169

Rosdiana, R. (2018). Faktor yang Berhubungan dengan Kejadian Tuberkulosis Paru di Rumah Sakit Umum Daerah Labuang Baji Makassar. Promotif: Jurnal Kesehatan Masyarakat, 8(1), 78. https://doi.org/https://doi.org/10.31934/promotif.v8i1.233

Sumarsih, T., \& Wahyuningsih, T. (2019). Pengaruh Relaksasi Spiritual terhadap Perubahan Tingkat Ansietas dan Stres Pasien Tuberkulosis Paru di RS PKU Muhammadiyah Sruweng. Urecol, 645-653

Sutarto, F. Y. S., Indriyani, R., \& Wibowo, A. (2019). Efikasi Diri pada Kepatuhan Minum Obat Anti Tuberkulosis (OAT). Jurnal Kesehatan, 10(3), 405-412 